\title{
MISCELLANEOUS NEW CHALCID-FLIES OF THE HYMENOPTEROUS FAMILY ENCYRTIDAE
}

\author{
By P. H. Timberlake \\ of the Citrus Experiment Station, Riverside, California
}

The family Encyrtidae is remarkable for its incomparably rich and diverse display of generic characters, in sharp contrast with certain other Chalcidoid families, such as the Pteromalidae, which are much more uniform in both appearance and structure. The number of genera of the Encyrtidae, although now amounting to over 300, will be gradually increased by future work, and the immensity of the group can be appreciated only by those who have had occasion to arrange or study collections of small parasitic Hymenoptera, especially from tropical regions. Only a smail amount of work has yet been done on these insects from the Tropics, however, except by Girault in Queensland, Australia, so that doubtless many interesting genera and species await description. The family is also by no means poorly represented in the temperate regions of the globe, and a few species have been recorded even from the Arctic Zone.

In the following pages seven new genera and nine new species are described, seven species of which come from North America or the West Indies, and one species each from Fiji and Victoria, Australia. This material has been reared in small part by myself, but for the most part it has been received for determination at various times and from various sources. Seven of these species were reared from Coccidae, and one was reared from Sympherobius, which preys upon Coccidae. The habit of the new species from Fiji is unknown, as the type specimen was not reared.

This paper gives the results of a series of studies made at the Graduate School of Tropical Agriculture and Citrus Experiment Station of the University of California at Riverside, California.

\section{VOSLERIA, new genus}

Vosleria is evidently allied to the Dinocarsis and Leptomastix group of genera, and although running with difficulty in Ashmead's table to the Leptomastix or Ectroma couplets, it does not agree closely in details with any of the included genera. In Girault's table

No. 2629.-Proceedings U. S. National Museum, Vol. 69, Art. 3. $81497-26-1$ 
it runs to Ameniscocephalus, but it differs in many important characters. In Mercet's table it runs to couplet 33, and is easily distinguished from the genera (Callipteroma to Dicarnosis) there set off by the slender antennae and by the peculiar wings and venation.

Genotype.-Vosleria signata, new species.

Female.-Head very large, considerably broader than the thorax, menisciform, thin frontooccipitally, the occiput only moderately concave, with the neck inserted distinctly above the middle but less than halfway to the vertex; as seen from above the outline is narrowly reniform, broadly rounded in front, and about commensurately emarginate in a broad curve at the occipital margin; as seen from the side the occipital margin is straight for most of its course, but curves inward at the top of the head, the curvature in front much less than that of a hemisphere, being a little more abrupt above than toward the mouth; as seen from in front the outline of the head is circular above the lower end of the eyes, but the cheeks are distinctly discontinuous with the outline of the eyes and strongly convergent toward the narrow and subtruncate oral margin, the mouth being relatively small. Eyes proportionately rather small, protuberant below, above almost touching the occipital margin, about twice as long as wide, their long axis coincident with the longitudinal axis of the head, their posterior margin nearly straight, the inner orbits nearly parallel but diverging through the curvature of the head as they approach the occipital margin; postocular area narrow; vertex extremely broad, or over one-half the total width of the head, the occipital margin acute; ocelli minute, arranged in a very large slightly obtuse-angled triangle, the posterior pair remote from the eye margins and nearly as far removed from the occipital margin. Cheeks as long as the width of the eyes, or about one-half the width of the frons, the genal suture obsolete; face convex and without scrobes, the antennae inserted rather close together just below the ocular line, which passes through the dorsal part of the sockets; space between the sockets not protuberant, but conforming to the curvature of the face and somewhat wider below than the length of the sockets.

Antennae slightly longer than the body, slender but not filiform; scape very long and cylindrical, about as long as the width of the head and nearly equaling the pedicel and first three funicle joints combined; pedicel relatively small yet twice as long as thick; flagellum distinctly compressed but not expanded, a little the widest at the middle, and clothed with numerous short bristly setae; funicle six-jointed, the joints decreasing greatly in length distad, but all longer than wide, and increasing in width to the juncture of the third and fourth joints, then decreasing in width; first funicle joint about four times as long as wide, the third twice as long as wide, 
each of the last three about one-half longer than wide, but distinctly decreasing in size distad; club elongate oval, rounded at apex, a little longer than the last two funicle joints combined, three-jointed, with the apical joint slightly the longest. Mandibles small relatively to the size of the head and with two short acute teeth at apex; the palpi not examined.

Thorax twice as long as wide, distinctly wider than the depth dorsoventrally, moderately convex above from side to side; posterior margin of pronotum rectangularly emarginate; mesoscutum considerably longer medially than at the sides, and less than twice as wide as long; axillae about one-half wider than long, rather narrowly separated medially, their posterior margin a little elevated above the scutellum; scutellum small, about two-thirds as long as the scutum, strongly depressed, hardly elevated at apex, but increasingly more elevated at the sides toward the base and sharply declivous, only slightly longer than wide, the apical angle somewhat less than $90^{\circ}$ and slightly rounded off, the sides a little convexly arcuate. Propodeum large, the median length about equal to two-thirds of the scutellum, yet fully twice as long at the sides as in the middle, gently sloping backward, convex from side to side, medially with a relatively large semioval depression the apex of which is contiguous to the apex of the scutellum, the margins of the depression hardly carinated; the metapleura not separated by a flexure from the disk of the propodeum.

Abdomen rather small, about two-thirds as long as the thorax and narrower; the outline as seen from above rather narrowly oval, the greatest width less than one-half of the length, the apex bluntly rounded; the dorsum deeply sunken in behind the first tergite, the apical tergite very large and covering most of the visible portion of the concavity; venter compressed and vomeriform at apex; ovipositor not protruded and entirely inclosed by the ventrites; cercal or vibrissal plates retracted beneath the first tergite, each with only one long vibrissa visibly projecting from this cavity.

Legs rather long and very slender, including even the femora; the hind femora compressed but not widened; the middle tarsi long and only slightly tapering, the first joint nearly as long as the following joints combined, the tibial spur distinctly shorter; hind tarsi slenderer than the middle pair and nearly as long.

Wings broadly spatulate in shape, the basal half narrow and somewhat constricted just before the point where the disk begins to widen; apical half broadly oval, the apical margin evenly and broadly rounded, the greatest width not much less than one-half the total length of wings; marginal fringe short and dense; disk deeply infuscated and with very dense short setae, relieved by four bare hyaline areas in addition to the costal cell, namely, an elongate 
oval or fusiform area on the posterior margin at base of wing; an oval spot at the constricted part of the disk extending obliquely basad from the submarginal vein not quite to the opposite margin; a narrow arcuate crossband with the concave side distad, situated just beyond the middle of the wing at the base of the widest part of the disk and just touching apices of the postmarginal and stigmal veins; and a narrow band at apical margin of the disk. Submarginal vein reaching almost to the middle of the wing, strongly sinuate or curved inward at the constricted region of wing; marginal and postmarginal veins equal, very thick and widest at their juncture, each fully four times as long as wide; stigmal vein forming a right angle with the postmarginal, about three-fourths as long and enlarged at apex, its apical margin very broadly emaginate, the four postules arranged in a curved line. Speculum very oblique, lying almost parallel with the marginal vein and apex of the submarginal and passing into the clear oval area at the constricted part of the disk, beyond this area continued and connecting with the basal clear area. Costal cell narrow except where the submarginal vein curves inward, mostly hyaline and bare excepting a row of setae on the basal third, and a marginal row of setae on the apical third. Setae on the veins very numerous but small, about equaling in size those between the speculum and the marginal vein, which are distinctly but not greatly larger than the remaining discal setae.

Head with very fine roundish reticulations and with numerous minute pin punctures on the frons, which become finer and closer toward the antennal sockets and much sparser toward the vertex, there being practically no punctures on the vertex behind the ocelli; mesoscutum finely reticulate, axillae and scutellum finely longitudinally punctato-reticulate and duller than the scutum; mesopleura microscopically reticulately shagreen d, but much more coarsely so on the posterior margin; abdomen very finely reticulate.

Sides of head behind the eyes, the face, checks, pronotum, mesoscutum, propodeum, abdomen, and legs provided with numerous appressed fine white stae, which are distinctly longer behind the eyes and on the propodeum; scutellum with very sparce, fine, incor.. spicuous setae and two rather long bristles at apex; frontovertex almost bare, the very few fine setae present being very inconspicuous; eyes with sparse, very short, erect setae.

Coloration metallic but not brilliant, the surface of body being moderately and not uniformly shiny.

Male.-Not known.

VOSLERIA SIGNATA, new species

Plate 1, figs. 1 and 7

Female.-Head shiny fuscous with an obscure bluish luster, the occiput above the neck yellowish brown, a small dot on each side 
of vertex at dorsal end of eyes and the antennal sockets brown, the oral margin narrowly and obscurely also brownish; mandibles brown, the teeth blackish; antennae wholly blackish, the scape with an obscure metallic luster; thorax and abdomen plumbeous or slightly greenish black, the metallish luster most apparent and greenish on the mesoscutum, the mesopleura the most shiny parts, their surtace no smoother than the scutum but without pubescence, the axillae and scutellum dullest but not matt; legs concolorous with body, the femora with a bluish or plumbeous luster, the articulations obscurely brownish, the tarsi yellowish brown and darker at apex, the spur of middle tibiae yellowish; wings dark brown with white spots and bands, the veins fuscous.

Length of body, 1.75; length of head, 0.695 ; width of head, 0.667 ; width of vertex at anterior ocellus, 0.388 ; thickness of head frortooccipitally, 0.306 ; length of antenna, 1.81; width of mesoscutum, 0.528 ; length of fore wing, 1.48 ; width of fore wing, $0.570 \mathrm{~mm}$.

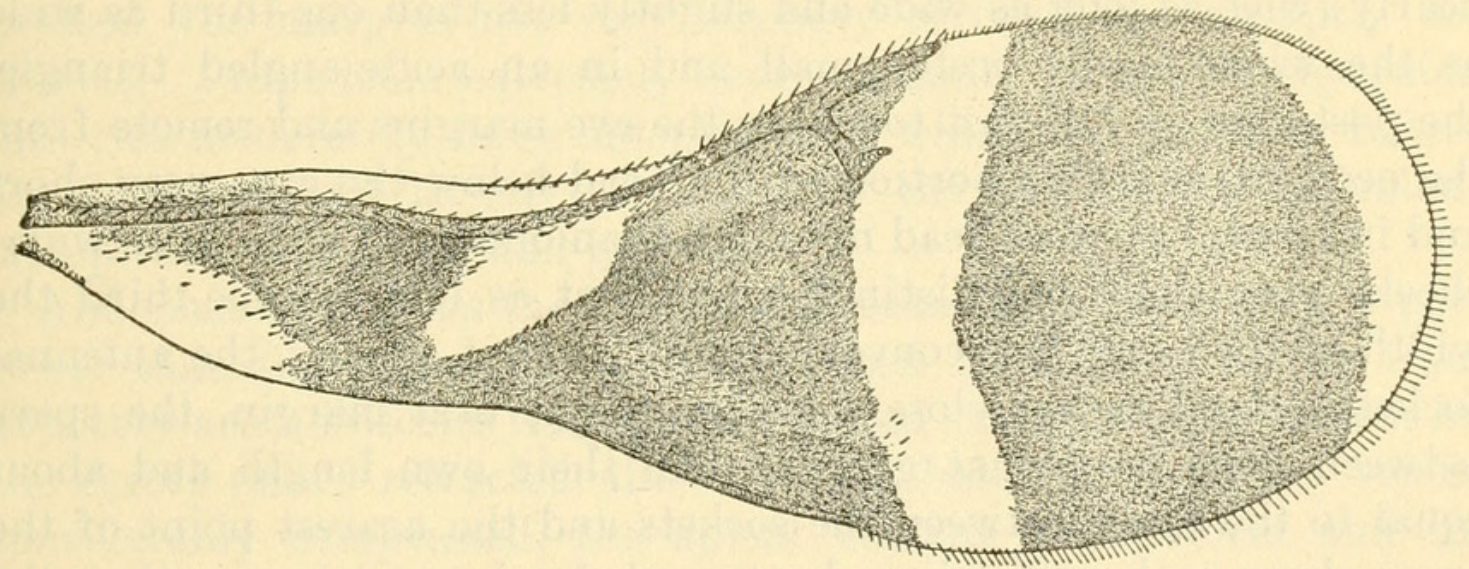

Fig. 1.-Vosleria signata timberlake. Fore wing of female

Described from one female (holotype) reared in 1918 from a species of Pseudococcus (California State Insectary No. 3971) collected at Sunshine, Victoria, Australia, by E. J. Vosler

Type.-Cat. No. 28113, U.S.N.M.

\section{CYRTOCORYPHES, new genus}

This genus has the habitus of Homalotylus Mayr and agrees in the general form of body, shape of head, and in the conformatiors of the antennae, legs, and wings, but differs from it especially in the essentially Ectromatine mandibles and abdomen and in other details. It is therefore really more closely related to the Ectroma group of genera. In Mercet's tables it runs out at couplet 36, but disregarding the postmarginal vein it would run Iairly well to Ectroma (Aglyptus Förster), from which it differs in having the marginal vein shorter, the postmarginal shortly reveloped, the mesoscutum without parapsidal lines, the axillae fused with scutellum, the differently shaped head with comparatively narrow vertex, etc. 


\section{Genotype.-Cyrtocoryphes viridiceps, new species.}

Female.-Head hemispherical, nearly as wide as long and about one-half as thick frontooccipitally as wide; as seen from in front the outline is nearly circular, but the eyes are slightly protuberant, especially below, and discontinuous with the cheeks, the latter converging a little toward the mouth, the oral margin truncate and a little wider than the distance between the lower ends of the eyes; as seen from above the outline is nearly semicircular, but more strongly rounded at the sides; as seen from the side the outline is also semicircular, with the curvature uniform from occipital to oral margin. Occiput nearly flat or only slightly concave above, the neck inserted near the middle; eyes large, broadly reniform, with the posterior margin moderately and broadly emarginate, widest near ventral end, where the width is a little more than one-half the length, rorsally almost touching the occipital margin; space between the eyes moderately wide, the part visible in dorsal view of head nearly twice as long as wide and slightly less than one-third as wide as the whole head; ocelli small and in an acute-angled triangle, the posterior pair almost touching the eye margins and remote from the occipital margin; portion of the head below the eyes very short and in frontal view of head not more than one-third as long as wide; cheeks very short but distinct, and about as long as one-third the width of the eyes; face convex, almost without scrobes, the antennal sockets placed rather close together at the oral margin, the space between them somewhat greater than their own length and about equal to the space between the sockets and the nearest point of the eyes; above each socket is a short scrobal sulcus no longer than the socket itself; face and cheeks separated by a slight angulation, which forms an obscure carinalike ridge continuous above with the inner orbits of the eyes.

Antennae about as long as the body, slender throughout; scape compressed but linear and of uniform width, including the radicle it is somewhat longer than the head; pedicel about thrice as long as wide, distinctly shorter than the first funicle joint and slightly longer than the second; flagellum cylindrical, rather thick, or a little wider than the apex of the pedicel; funicle six-jointed, clothed with short, rather coarse, decumbent setae, the joints decreasing in length distad, the first about four times as long as thick, the sixth not quite twice as long as thick; club three-jointed, elongate oval, rounded at apex, hardly wider than the funicle and about as long as the last two joints and one-half of the fourth joint of the funicle combined.

Mandibles rather small, narrow in frontal view and with two acute teeth at apex, of which the inner one is the larger. Maxillary palpi short, tapering, almost straight, four-jointed; two basal joints 
about twice as long as thick, the third somewhat shorter, the fourth longest but not quite as long as the two preceding joints combined, provided with two or three short setae on the inner side near apex and one longer seta at the apex. Labial palpi three-jointed, basal and apical joints each about thrice as long as thick, the middle joint nearly twice as long as thick.

Thorax robust, about one-half longer than wide, not quite so thick dorsoventrally as wide and convex above; pronotum strongly arcuate; mesoscutum nearly twice as wide as long, its posterior margin sinuate and with a small median lobe projecting over the inner tips of the axillae; the latter rather long at the sides, somewhat separated medially by the projecting lobe of the mesoscutum but actually meeting underneath this, the suture separating them from the scutellum very indistinct or obsolescent, so that they are practically fused with the scutellum; excluding the axillae the scutellum is quadrangular with the apex acute, its disk rather strongly depressed, the margins not very strongly elevated yet abruptly declivous. Propodeum extremely short medially or almost separated into two moderately large sidepieces, of which the posterior halves are declivous and largely concealed by the base of the abdomen; metapleura very small and narrow.

Abdomen as long as the head and thorax combined, its base narrower than the thorax, its outline as seen from above in the form of a very acute isosceles triangle; the dorsal surface deeply sunken in, the cercal plates retracted almost to the basal margin; the venter considerably compressed, the apical ventrite vomeriform and inclosing the ovipositor, which is slightly protruded.

Legs long and slender, excepting that the front and hind femora are compressed, the front femora being broader than the hind pair, middle legs distinctly longer than the hind pair, the tarsi tapering, the tibial spur long; hind tarsi about as long but much slenderer than the middle tarsi.

Wings rather small and narrow, but reaching much beyond the apex of abdomen; discal setae very fine and dense, becoming finer and hyaline in the arcuate band just beyond the apex of venation, the basal fourth of the disk bare; speculum narrow and very distinct, yet reaching hardly more than one-half the way across the disk; submarginal vein slender, marginal about twice as long as wide, postmarginal very short but distinct, stigmal vein about as long as the marginal and postmarginal veins united, and reaching about opposite to the middle of the costal margin.

Head with a very fine, dense, thimblelike puncturation and with sparse, well scattered, very minute pin punctures; mesoscutum smooth and shiny yet with a delicate, very fine reticulation and with minute setigerous punctures; axillae and scutellum opaque from a 
dense microscopic thimblelike puncturation, which is finer than that of the head; pleura finely reticulately shagreened, abdomen finely reticulate.

Eyes bare, the frontovertex and face with sparse, semierect, very fine short setae, the face below the eyes with equally fine appressed whitish pubescence; mesoscutum with rather numerous fine and short, dark-colored setae; the base of the scutellum with a few considerably coarser setae and its apex with a pair of long bristles; sides of propodeum moderately densely covered with glistening white appressed pubescence, the metapleura and hind coxae bare, abdomen apparently wholly bare.

Coloration rather brilliantly metallic; the antennae blackish, but with the club white.

Male.-Not known.

CYRTOCORYPHES VIRIDICEPS, new species

Plate 1, fig. 5; plate 2, fig. 19, $19 a$

Female.-Head bright metallic emerald green (Ridgway), changing to blue green on the face and cheeks below the eyes; thorax and abdomen metallic dark violet blue, except the axillae and scutellum, which are matt fuscous or with a metallic sheen only when viewed at a very oblique angle from the side; antennae fuscous, the club white; coxae and hind femora concolorous with the thorax, front and middle femora and all the tibiae fuscous, the spur of middle tibia and the tarsi brownish yellow. Wings with a broad discal band deeply infuscated, reaching from the middle of the submarginal vein to apex of the stigmal, its distal margin strongly rounded, the basal margin squarely truncate; following the discal band is a curved, rather narrow, clear band imperceptibly grading distad into the faintly infuscated area on apical fourth of the disk; somewhat less than basal fourth of the wing is hyaline, but with an infuscated streak from the base of the submarginal vein along the posterior margin for a short distance; veins brown, but the part of the submarginal vein opposite the hyaline area is nearly transparent.

Length of body, 1.28; length of head, 0.426 ; width of head, 0.410 ; thickness of head frontooccipitally, 0.249 ; width of vertex at posterior ocelli, 0.132 ; length of antenna, 1.30 ; width of mesoscutum, 0.426 ; length of fore wing, 1.11; width of fore wing, $0.440 \mathrm{~mm}$.

Described from one female (holotype) collected at Ba, Letu Vitu, Fiji, in 1906 (F. Muir).

Type-Cat. No. 1240, Hawaiian Sugar Planters' Experiment Station. 
PSEUDORHOPUS, new genus

Rhopus MAYr, 1875 (excluding male), Verh. zool.-bot. Ges. Wien, vol. 25, p. 690.-Girault, 1915, Journ. New York Ent. Soc., vol. 23, p. 169.-Mercet, 1921, Fauna Iberica, Himen., Fam. Encértidos, p. 83, figs. 8-10.

Pseudorhopus is a new name for Rhopus of authors, not Förster, and has for its type Encyrtus testaceus Ratzeburg. Mercet has cited testaceus as the type of Rhopus Förster, but this can not be, as Förster cited Encyrtus piso Walker as the type. Mayr synonymized piso with testaceus with some doubt, as he had not seen the type of piso, and I am now able to show with considerable certainty that the males which he placed with testaceus, including the specimen of piso received from Walker, have nothing to do with testaceus. This conclusion is based on the study of a fine series of a closely related North American species, including both sexes, the males being very similar to the females except in the primary sexual characters, and like them in having a five-jointed funicle. The male of this species (described below as hartmani) is so exceedingly like the female that I believe it is very likely that Mayr overlooked the true male of testaceus in the large series of specimens reared from Physokermes piceae Schrank, which he thought were all females.

As the genus Pseudorhopus has the characters assigned to Rhopus by Mayr, and has been further elucidated by Girault and Mercet, it does not need to be redescribed here. The broad edentate mandibles, the shore antennae with the five-jointed funicle and entire club, the short submarginal vein, punctiform marginal vein, short stigmal and postmarginal veins, and the short tarsal joints are all peculiar characteristics by reason of which the genus can hardly be mistaken. Although the mandibles are similar to those of Encyrtus, I do not believe that Pseudorhopus is closely allied thereto. Mercet has suggested its affinity to Arrhenophagus Aurivillius, and it is perhaps the nearest approach to that isolated genus of all the Encyrtinae.

Rhopus itself was described by Förster in rather negative terms, the only positive characters given being the gradual transition of the frontovertex into the face (not separated by a sharp angulation), the strongly depressed body and nonmetallic coloration. Nothing is said about the antennae having a five-jointed funicle, and the genus is placed with others having the normal number of joints. The type species piso was described by Walker as having the body depressed; the head small, transverse, and very short, the antennae slender, filiform, pilose, almost as long as the body, the funicle sixjointed, the joints long and linear, the club fusiform and nearly twice as long as the preceding joint; the wings long, narrow, and with a short marginal fringe. Judging from these characters it seems to me that Rhopus is very close to Xanthoencyrtus Ashmead and probably the same. 
PSEUDORHOPUS HARTMANI, new species

Plate 1, figs. 2 and 11 ; plate 2, fig. 14

Female.-Head slightly wider than long, thin frontooccipitally, as seen from in front broadly rounded above, the sides well rounded and a little convergent toward the broad truncate oral margin; occiput perfectly plane on lower half, moderately concave above the middle, with the neck inserted at the middle of this concavity, considerably above the center of the occiput as a whole; eyes small, nearly circular, only slightly longer than wide, the ventroposterior margin slightly flattened; frontovertex much broader than long, the ocelli in a very obtuse angle, the posterior pair about one-half as far from the eye margins as their distance apart and much closer to the occipital border; cheeks rather long and equal to the length of the eyes. Face with a very distinct large depression with sloping sides, reaching from a little above the oral margin at the insertion of the antennae far upward between the eyes, the inferior part divided by the triangular prominence between the antennae; this prominence being broadly convex, not very high, a little longer than its greatest width and reaching upward a little beyond a line drawn tangent to the lower margin of the eyes; superiorly the depression is separated from the frontovertex by an angulation.

Antennae inserted far apart slightly above the oral margin; scape flattened, linear, and slightly wider on the basal half; pedicel twice as long as thick, as long as the following three and one-half joints combined; flagellum rather strongly clavate, the first three funicle joints subequal, slightly wider than long, and increasing slightly in width distad, the fourth and fifth joints increasingly both wider and longer, the fifth being considerably wider than long; club a littio longer than the entire funicle, distinctly increasing in width toward the apex, where it is obliquely truncate, the greatest width nearly twice that of the preceding joint.

Mandibles with a very broad truncate margin at apex; maxillary palpi two-jointed, the basal joint a little longer than thick, the apical joint about three times as long, tapering and with two setae at apex; labial palpi with only one fusiform joint, which is about onethird as long as the entire maxillary palpus.

Thorax short, robust, about as thick dorsoventrally as broad and rather convex above; pronotum strongly arcuate and hardly visible in dorsal view; mesoscutum large, about one-third broader than long, its posterior margin straight; axillae much wider than long, acute, and meeting medially; scutellum distinctly four-sided, longer than wide and reaching almost to the base of the abdomen, the apex rather acutely angled, the sides abruptly declivous, the disk depressed; propodeum very short medially, but lengthening at the 
sides. Abdomen somewhat shorter than the thorax, triquetrous in shape, the dorsal surface rather depressed; ovipositor entirely concealed and inclosed by the ventrites, and when dissected out it proves to be very short and minute.

Legs rather short but slender; tarsi of the middle legs about twothirds as long as the tibiae, cylindrical, and not at all thickened at base, not much shorter than the hind tarsi, the first joint as long as the next two combined, the second to fourth joints equal and no longer than thick, the fifth slightly longer than those just preceding; spur of middle tibiae as long as the basal joint of the middle tarsi. Wings moderately wide, the marginal fringe short; submarginal vein not quite reaching to the middle of the wing, the stigmal given off just before the vein reaches the costal margin; the postmarginal vein very short, both it and the marginal taken together being practically punctiform, stigmal vein short, only slightly thickened at apex and not very distinct; speculum moderately narrow and interrupted below the middle.

Head, thorax, and abdomen smoothish, with a fine reticulate sculpture; head very finely and rather indistinctly reticulate except on the frontovertex, where the reticulations are coarser and the surface is somewhat roughened; mesoscutum with a scaly reticulation, the reticulations of the scutellum somewhat longitudinally lengthened. Pubescence throughout short, fine, and inconspicuous, but rather abundant on the face, on the frontovertex, and along the inner orbits of the eyes, and sparser on the thorax; eyes nearly bare.

General color of the body nearly ochraceous orange (Ridgway), the cheeks posteriorly, occiput, under parts of thorax, and the legs paler yellow; antennae about concolorous with the face; apical joint of the tarsi more or less fuscous; wings hyaline, with a minute smoky spot beneath the middle of the stigmal vein, the apical part of the submarginal vein also bordered with a slight infuscation.

Length of body, (0.733 to) 0.800 ; length of head, 0.329 ; width of head, 0.388 ; width of frontovertex, 0.216 ; length of antenna, 0.629 ; width of mesoscutum, 0.334 ; length of fore wing, 0.893 ; width of fore wing, $0.374 \mathrm{~mm}$.

Male.-Very similar to the female, but the antennae are somewhat less clavate, the scape wider, the pedicel distinctly constricted at apex, the club smaller and oval; coloration noticeably darker, the scutellum brown and becoming fuscous at the apex, the abdomen also more or less brownish, but the under parts of thorax, the legs, and antennae colored about as in the female.

Length of body, (0.766 to) $0.926^{1}$; length of head, 0.306 ; width of head, 0.341; width of frontovertex, 0.207; length of antenna,

1 This specimen is probably not actually larger than any of the females, but the abdomen became swollen in the preserving fluid and did not collapse after mounting. 
0.558 ; width of mesoscutum, 0.334 ; length of fore wing, 0.841 ; width of fore wing, $0.384 \mathrm{~mm}$.

Described from 32 females and 11 males (holotype female, allotype, and paratypes) reared from a species of Lecanium (No. 57), Austin, Texas, May 15, 1913 (Carl Hartman), No. 61. The specimens were preserved in spirits before being mounted and many of them are considerably bleached. The head of one of the male paratypes has been lost.

This species is distinguished from $P$. testaceus (Ratzeburg) by the more clavate antenna with the club obliquely truncate and by the longer basal joint of the middle tarsi; testaceus is also said to have the body considerably depressed, but this is not true of hartmani. The coloration of the two species is apparently about the same. Rhopoideus fuscus Girault, which was later transferred by its author to Rhopus, should be cited as Pseudorhopus fuscus and is distinguished from both hartmani and testaceus by the much darker coloration and larger size.

Type.-Cat. No. 28141, U.S.N.M.

\section{HEXACNEMUS, new genus}

In Mercet's table of genera Hexacnemus female runs to couplet 62, where it runs out, as it agrees with neither alternative, the abdomen being depressed and the antennae strongly filiform. In Girault's table the female runs to the couplet containing Isodromoides and Neocopidosomyia, but the face is not inflexed and the marginal vein is punctiform. In Ashmead's table it runs to Pentelicus, but it disagrees in many particulars with that genus. In Howard's table of the Tetracnemini the male runs to Hexacladia on account of the sixbranched antennae, but is certainly not even closely allied to that very characteristic genus. Howard's group Tetracnemini, with the exclusion of Hexacladia and Tanaostigma, is perhaps a natural group of which Hexacnemus forms a very distinct member.

Genotype.-Hexacnemus armitagei, new species.

Female.-Head menisciform, thin frontooccipitally, about as wide as the thorax and a little wider than long; in frontal view it is fully rounded below and on the sides but depressed above, with a slight emargination on each side of the vertex at the margin of the eyes; in dorsal view appearing gently rounded in front, strongly rounded at the sides and strongly incurved at the occipital margin; in side view not quite uniformly convex from oral to occipital margin, being slightly depressed below and thickest frontooccipitally a little above the middle; occiput deeply concave, the dorsal margin acute. Frontovertex moderately broad and widening below, the whole area between the eyes over twice as long as its least width; ocelli arranged in a slightly obtuse-angled triangle, the posterior pair about one- 
half of their own diameter or slightly less from the margin of both the eyes and the occiput; eyes moderately large, oval, vertical, contiguous dorsally with the occipital margin, about as wide as onethird of the whole head; cheeks almost as long as one-half the width of the eyes, the genal suture distinct; face short and broad, the scrobes short, linear, acutely converging yet meeting above in a curve, the interspace very slightly convex and about twice as long as wide.

Antennae inserted rather close together and very close to the clypeal margin, the sockets being separated from each other by a space about equal to their own length, and divided from the clypeal margin by a space somewhat less than their own width. Scape long and cylindrical, including the radicle somewhat longer than the eye; pedicel about twice as long as thick and nearly equal to the following joint in both length and width; flagellum moderately long and cylindrical, the funicle joints increasing just perceptibly in thickness distad; funicle six-jointed, the first joint about twice as long as thick, the following joints gradually shortening, the last one only slightly longer than thick; club solid, cylindrical, about equal to the last three funicle joints combined, its outer surface collapsing in the form of a furrow.

Mandibles moderately wide, expanding slightly at apex, the teeth rather long and stout, spreading a trifle, a little rounded at their tips, the middle one slightly larger than the other two. Maxillary palpi moderately long, four-jointed, the first two joints about as long as thick, the third as wide as long, the fourth somewhat thicker and fusiform, about as long as the first two joints combined; labial palpi, rather short, stouter than the basal joints of the maxillary pair, three-jointed, the middle joint very short and rather wider than long, the apical and basal joints subequal, rather longer than the basal joint of the maxillary pair, the apical joint oval.

Thorax robust, strongly convex above, with the thickness dorso- ventrally not quite equal to the width; pronotum strongly arcuate; mesoscutum large, its median length a little more than one-half the width, its posterior margin convexly arcuate, especially medially; axillae short, over twice as wide as long, the inner tips narrowly truncate and meeting, but normally concealed by the posterior margin of the mesoscutum so that the axillae appear to be slightly separated; scutellum large, slightly longer than wide, the sides moderately bulging, well elevated and abruptly declivous, the apex rather acutely rounded, the disk strongly depressed; propodeum short medially but lengthening toward the sides, and strongly arched from side to side.

Abdomen about as long as the thorax, ovate; the dorsum depressed, the cercal plates situated a little basad of the middle; the 
venter with a strong median plica, the ventrites entirely inclosing the ovipositor to the apex of abdomen; the ovipositor, however, strongly protruded, the sheaths slender, cylindrical, and nearly onehalf as long as the abdomen.

Wings rather wide and reaching to the apex of the ovipositor; the disk moderately densely covered with very short, pale setae, the basal area beneath the submarginal vein bare; the speculum narrow, separated from basal area by a row of about seven coarser setae, but uniting therewith at a point a little more than one-half way to the posterior margin; marginal fringe extremely short or obsolescent; venation short or extending but little more than one-third of the length of the wing, the costal cell rather wide; submarginal vein not thickened distally, the marginal punctiform, the stigmal emitted before the vein quite reaches the margin, the postmarginal extremely short, both it and the marginal taken together being strongly thickened and no longer than wide, the stigmal rather short, somewhat curved, and not much enlarged at apex. Hind wings broad, the costal cell wide and extending to the hooklets, the marginal fringe better developed than in the fore wings.

Legs of moderate length and normal structure; the middle tarsi strongly tapering, the first joint nearly as long as the following joints combined; spur of the middle tibiae stout and almost as long as the first joint of the middle tarsi; hind tarsi rather slender, nearly as long as the hind tibiae, the basal joint about as long as the next three joints combined, the last four joints nearly equal, with the fourth joint somewhat the shortest.

Head, except in the scrobal region of face, with very large refulgent thimblelike punctures, which are rather crowded or almost confluent in the space lying between the eyes and the scrobes but sparser on the frontovertex, the surface otherwise being very finely reticulate or equally finely rugulose on the vertex; mesoscutum very finely reticulate and with seriate shallow pin punctures; scutellum duller than the scutum because of the dense microscopic thimblelike puncturation.

Eyes bare; the large punctures of head each bearing a short subappressed glistening white seta; mesoscutum with similar more flattened setae, interspersed or replaced with blackish setae along the anterior margin; scutellum with a few fine scattered dark-colored setae, and a pair of long fine bristles at the apex. Coloration metallic, but not brilliant.

Male.-Similar to the female, except in the characters of the head, antennae, and abdomen. Head somewhat thinner frontooccipitally and considerably more flattened anteriorly; in side view appearing convex only dorsally, and considerably depressed anteriorly in dorsal view; eyes less than one-half as large as in the female and 
about one-third longer than wide; frontovertex broader, being fully one-half wider than long; ocelli very large, in a more obtuse-angled triangle, the posterior pair touching the acute occipital margin and removed by one-half of their own diameter from the eye margins; cheeks fully as long as the eyes; face with a median rounded ridge extending from the clypeal margin to a little above the antennal sockets, or about two-thirds of the length of the face, and somewhat widening above the antennae; scrobes uniting above in a large common impression, somewhat triangular in shape, with the apex truncated and with sloping walls; antennal sockets situated in slight depressions on each side of the facial prominence about halfway between the ocular line and the clypeal margin, yet noticeably closer to the clypeal margin than to the nearest point of the eye.

Scape moderately long, reaching somewhat beyond the scrobal impression, slender and compressed, considerably shorter and a little stouter than in the female; pedicel hardly longer than thick; funicle six-jointed, each joint with a long, slender, cylindrical branch of which the second is longest, the following gradually shortening, the sixth about two-thirds as long as the second; basal part of first joint no longer than thick, that of second joint slightly longer, the following joints gradually lengthening, the base of the sixth being about thrice as long as thick; club solid, compressed, clavate, and widest near the apex, about as long as the basal parts of the last three funicle joints combined; all parts of the funicle and club provided with fine, soft, short setae.

Abdomen triangular in shape, strongly depressed, about one-half as long as the thorax, the venter with a median plica.

\section{HEXACNEMUS ARMITAGEI, new species}

Plate 1, fig. 10 ; plate 2, figs. $16,20,23$, and $23 a$

Female-General color metallic black, the head, pleura, and abdomen more lustrous; occiput with a strong green luster, cheeks bluish, the face, especially the antennal prominence and the scrobes, with a bluish and purple luster, the large punctures with a pale greenish luster; mesoscutum slightly greenish, the axillae and scutellum opaque, although the margins of the latter are metallic green; pleura dark metallic blue; abdomen bluish green, the apical tergite with two narrow, parallel, longitudinal, slightly impressed yellowish lines at the middle, the ovipositor black but becoming slightly brownish beneath at base; legs bluish black, the front tibiae, basal half of middle tibiae, and all the tarsi brownish yellow, the front and hind tarsi dusky above, with the last one or two joints fuscous, the middle tarsi with only the last joint fuscous; antennae black, mandibles brown; wings clear, whitish hyaline, becoming nearly invisible when mounted in balsam, the veins brownish. 
Length of body, (1.66 to) 1.93; length of head, 0.608 ; width of head, 0.723 ; width of vertex at ocelli, 0.261 ; length of antenna, 1.50; width of mesoscutum, 0.645 ; length of fore wing, 1.53 ; width of fore wing, 0.702 ; length of ovipositor, $0.325 \mathrm{~mm}$.

Male.-Similar to the female in coloration, the pleura, sternum, and venter more strongly bluish and purple, the apex of the abdomen above also brilliant blue and purple; the white setae of mesoscutum sometimes more or less numerous, or replaced with blackish setae.

Length of body, (1.60 to) 1.83; length of head, 0.601 ; width of head, 0.784 ; width of vertex at ocelli, 0.386 ; length of antenna, 1.42 ; width of mesoscutum, 0.716 ; length of fore wing, 1.72 ; width of fore wing, $0.813 \mathrm{~mm}$.

Described from eight females and nine males (holotype female, allotype, and paratypes) reared from Hemerobiid cocoons collected November 5 and 30, 1919, at Ojai Valley, California (H. M. Armitage). Two species of Sympherobius were reared from the same lot of cocoons, one of these being S. californicus Banks.

Type.-Cat. No. 28142, U.S.N.M.

\section{AZTECENCYRTUS, new genus}

This genus has much the habitus of Homalotylus Mayr, and agrees with it in many important characters, but differs in the shape and dentition of the mandibles, the length of the antennae, and particularly that of certain joints, such as the scape, pedical, and first funicle joint, and in having the head thicker and more hemispherical, the wings narrower, with the stigmal and postmarginal veins more unequal and much less nearly parallel, the surface of the body much smoother and shiny, but not polished, and the coloration wholly nonmetallic. Aztecencyrtus also closely resembles Brethesiella Porter in many respects.

Genotype.-Aztecencyrtus flavus, new species.

Female.-Head hemispherical, rather thick frontooccipitally, the curvature uniform from occipital to oral margin; in dorsal view appearing semicircular but more strongly rounded on the sides than in front, the occipital margin very slightly arcuately emarginate; as seen from the side the outline is somewhat semicircular, with the curvature considerably less at the face than dorsally; as seen from in front the length and width are about equal, the outline fully rounded above, the sides considerably less rounded, the cheeks converging a little toward the broad truncate oral margin. Occiput only very slightly concave, the neck inserted near the middle, the dorsal margin distinctly angled; eyes moderately large, about one-half longer than wide, oval, and widest near the anterior end, the inner orbits parallel as seen in dorsal view of head; frontovertex twice as long as wide, the width distinctly less than one- 
third the total width of head; ocelli in an equilateral triangle, the posterior pair remote from the occipital margin and almost touching the eye margins; cheeks short, but not much shorter than the width of the eyes; face convex, the scrobes rery small, suboval, not much longer than their distance apart, each containing the small round antennal socket and separated from each other by the broad low prominence between the antennae, which is about twice as long as wide, parallel-sided, not at all protuberant, and merging above into the contour of the face.

Antennae inserted moderately far apart, rather close to the oral margin; scape short in comparison with Homalotylus, cylindrical, a little thicker at the middle, including the radicle nearly as long as the pedicel and funicle combined, but much too short to reach to the anterior ocellus, pedicel very short or hardly longer than thick; funicle six-jointed, cylindrical, and increasing very slightly in thickness distad; the first joint ringlike, more than twice as thick as long, hardly more than one-fourth as long as the next joint; the other five joints subequal in size, the second and third as long as wide, the sixth somewhat wider than long; club, except the extreme base, missing in the unique type, but the remnant indicates that it is at least somewhat wider than the funicle.

Mandibles unusually short and broad, with three coarse, spreading, acute teeth, the middle tooth the largest, the outer one much the smallest, the apex lying in the same plane as the base and moderately curved inward. Maxillary palpi short, four-jointed, the basal joint very short, transverse, the second about thrice as long as thick, the third one-third shorter than the second, the fourth much thinner than the preceding joint and about as long as the second; labial palpi two-jointed, the joints about equal in length, the first thrice as long as thick, the second oval and thicker.

Thorax fully twice as long as wide, depressed, the thickness dorsoventrally less than the width, the parts of the mesonotum lying in one plane; pronotum moderately arcuate; mesoscutum twice as wide as long; axillae large, broadly contiguous at inner tips; scutellum rather small, the sides slightly bulging, abruptly declivous and moderately elevated, the apex rather acutely rounded, the disk depressed, the length and basal width about equal; propodeum moderately large, much shortened medially, transversely convex, and considerably sloping toward the apex.

Abdomen about two-thirds as long as the thorax, somewhat less than twice as long as wide, depressed above, the outline in the form of an oval strongly truncated at basal end; cercal plates situated a little beyond the middle; venter slightly compressed, the sides gently sloping to the median line, the last ventrite reaching to the apex and inclosing the internal part of the ovipositor, which reaches ap- 
parently to the base of the abdomen; extruded part of ovipositor very long and slender and somewhat longer than the abdomen.

Legs long and slender, much as in Homalotylus, but the front and hind femora are much less compressed and much narrower, the hind tarsi are very slender and filiform, whereas the middle tarsi and tibial spur are like Homalotylus. Wings long and narrow, and very similar to Homalotylus; submarginal vein nearly straight, not enlarged distad, the setae on it very fine; marginal as in Homalotylus; stigmal and postmarginal veins moderately long and shorter than in Homalotylus, the stigmal enlarged at the apex, forming an acute angle with the postmarginal and not parallel with the margin; marginal fringe very fine, short and dense; disk of wing with a transverse infuscated band which is narrower and fainter than in Homalotylus, the apical half of disk clear and uniformly setose, the base of disk nearly bare out to the infuscated band; speculum narrow above and reaching to the base of the stigmal vein, broadening below at middle of disk where it passes out of the infuscated band and joins the nearly bare area at base of wing; costal cell bare except for one row of fine setae next to the margin of the wing in the apical third.

Sculpture extremely fine and microscopic throughout; the frontovertex dull from very shallow, close, thimblelike punctures; the mesonotum somewhat shiny and smooth and with a delicate microscopic reticulation; the propodeum smooth and considerably polished; the pleura with a more or less longitudinal reticulation coarser than that of the mesoscutum, but the propleura and the mesopleura anteriorly are equally finely striolate-reticulate; abdomen slightly more coarsely reticulate than the mesoscutum.

Pubescence very fine and short, white or whitish, and apparently not very dense except on the metapleura and hind coxae, where it is of the same type as in Homalotylus; the eyes almost bare. Coloration mostly yellow, nonmetallic, the antennae yellowish with the club apparently not paler.

Male.-Not known.

\section{AZTECENCYRTUS FLAVUS, new species}

Plate 1, fig. 8 ; plate 2, figs. 22, $22 a$

Female.-Face with sparse glistening white pubescense, the setae arranged in a row on the lateral margins of the prominence between the antennal scrobes and evenly distributed on the face and cheeks exterior to the scrobes; pubescence of mesonotum almost all denuded in the type, but apparently sparse, fine, and whitish; abdomen nearly bare, but there are a few fine whitish setae on each side except at base and apex; ovipositor sheaths with sparse appressed setae; pubescence of legs and antennae also very fine and short. Nearly 
bare area at the base of wing, with a few fine, nearly transparent setae arranged in about four oblique rows more or less distinctly continuous with the rows of setae between the speculum and the apex of the submarginal vein.

Frontovertex, most of face and cheeks, upper part of occiput, pronotum and mesonotum, anterior end of the mesopleura, about the apical third of abdomen and sides of venter nearly capucine yellow (Ridgway) ; oral margin of face and cheeks, lower part of occiput, propleura, posterior margin of pronotum very narrowly, a little more than the basal third of abdomen, the antennae and protruded part of the ovipositor sheaths paler or about light orange yellow (Ridgway); the legs in part and medial line of venter considerably paler or about pale orange yellow (Ridgway), although the coxae, femora, and tarsi are more whitish and the hind tibiae pale brown, darker at base and light at apex; apex of scutellum, the metanotum, and the propodeum about antique brown (Ridgway), the metapleura and posterior half of mesopleura about raw sienna (Ridgway) ; a narrow transverse band at middle of abdomen nearly black, covering about one-fifth of the whole length and passing slightly over onto the sides of the venter. Wings hyaline, the infuscated crossband beneath the marginal and stigmal veins interrupted just below the middle of the disk by a longitudinal pale streak parallel with the posterior margin, the band below the interruption somewhat paler; a small brown spot also present on both sides of the base of the submarginal vein; most of the submarginal vein very pale, the rest of the venation brownish.

Length of body, exclusive of ovipositor, 1.78; length of head, 0.521 ; width of head, 0.542 ; thickness of head frontooccipitally, 0.332 ; width of frontovertex, 0.160 ; length of scape, 0.285 ; length of pedicel and funicle combined, 0.329 ; width of mesoscutum, 0.568 ; length of fore wing, 1.445 ; width of fore wing, 0.497 ; length of protruded part of ovipositor, $0.867 \mathrm{~mm}$.

Described from one female (holotype) reared from Icerya palmeri Riley and Howard, collected June 28, 1897, at Frontera, Tabasco, Mexico, on the bark of a dyewood tree called "moral" (Dr. C. H. T. Townsend), U. S. Insectary No. $4274^{\circ}$.

Type.-Cat. No. 28143, U.S.N.M.

\section{TACHARDIOBIUS, new genus}

In Mercet's table Tachardiobius runs to Metaprionomitus Mercet; it is distinguished therefrom by the flattened face, strongly sulcate scrobes, emarginate anterior margin of the frons, the obsolescent postmarginal vein, the longer stigmal and the nonmetallic color; the male differs in having much shorter nonverticillate hairs on the antennae and in having all of the funicle joints cylindrical. 


\section{Genotype.-Tachardiobius nigricans, new species.}

Femate-Head rather thick frontooccipitally, about as long as wide, the face abruptly inflexed but the frons not prominent; dorsal surface of the head well rounded at the sides, depressed medially; in frontal view the outline is subcircular, well rounded on the sides, depressed above; in side view the outline is triangular, with the dorsal side not more than one-half as long as either of the other sides, the facial side straight, the other two sides slightly bulging. Occiput moderately concave, its dorsal margin rather acute; eyes rather small, strongly convex, a little longer than wide, the longer axis oblique to the longitudinal axis of the head; frontovertex comprising more than one-third of the total width of head, a little longer than wide, its anterior margin forming an angle of about $90^{\circ}$ with the face and deeply notched medially; ocelli large, arranged in a nearly equilateral triangle, the posterior pair somewhat less than their own diameter from the eye margins and about as far from the occipital margin; cheeks broad, convex, and a little shorter than the transverse diameter of the eyes, the genal suture obsolete; face very flat, extending well upward between the eyes, the scrobes in the form of narrow, deep sulci which meet in an angle above and notch the anterior margin of the frons; the oral margin broadly and rather deeply emarginate, exposing the labrum, which bears a rather dense fringe of longish setae.

Antennae inserted rather far apart, about halfway between the oral margin and the ocular line; scape rather long, linear, and a little compressed, reaching slightly beyond the plane of the frons, and including the radicle slightly longer than the pedicel and first four funicle joints combined; pedicel slightly less than twice as long as thick, a little shorter than the first two funicle joints combined; flagellum moderately clavate, the funicle six-jointed, the first joint about one-third longer than thick, the sixth joint as wide as long; club three-jointed, oval, wider than the funicle and a little shorter than three preceding joints combined.

Mandibles with a small acute ventral tooth and a moderately broad inner truncation, the apex, however, not in the same plane with the expansion of the base, as is usual in cases with this type of dentition. Maxillary palpi short and slender, four-jointed, the two middle joints distinctly thicker, the second as long as wide, the first and third about one-half longer than the second, the fourth fully twice as long; labial palpi very short, three-jointed, the basal joint about one-half longer than thick, the last two joints very short and subequal.

Thorax robust, strongly convex above, about one-third longer than wide; pronotum strongly arcuate; mesoscutum about twice as wide as long; axillae short, transverse, and acutely meeting medially; 
scutellum a little longer than wide, rather acutely pointed at apex, the disk somewhat depressed medially, but the sides strongly elevated, at first rounded, then abruptly declivous; propodeum very short, even at the sides, and sloping strongly backward, mesopleura considerably narrowed anteriorly and distinctly emarginated on the dorsal margin opposite the root of the fore wing.

Abdomen about as long as the thorax, broadly oval and depressed, or sometimes shrinking so that the dorsal surface becomes more or less sunken in; cercal plates situated beyond the middle of the lateral margins; ovipositor sheaths barely projecting beyond the apex, the spicula free and inserted near base of abdomen.

Legs normal in length and structure; middle tarsi stouter than the hind pair, tapering, the basal joint not quite so long as the next four joints combined; spur of middle tibiae somewhat shorter than the first joint of the middle tarsi. Wings reaching far beyond apex of the abdomen, moderately broad and well rounded at apex; disk including basal area with very short and dense setae, the marginal fringe short and dense; speculum very narrow but distinct, extending obliquely across the disk; apex of venation reaching nearly to the middle of the costal margin, the submarginal vein almost straight and not enlarged distad, marginal vein punctiform, the postmarginal nearly but not quite entirely obsolete, stigmal vein moderately long, at an angle of about $45^{\circ}$ with the costal margin, slender at base and triangularly enlarged toward apex.

Face, cheeks, collar of pronotum, and the mesonotum uniformly and very finely subrugulosely reticulato-punctate and rather dull; frontovertex with somewhat coarser, more thimblelike, reticulate punctures; propleura very finely and closely longitudinally lineolate; mesopleura smoothish, but with dense microscopic reticulato-lineolations; metanotum and propodeum smooth; abdomen finely reticulate, not at all rugulose but considerably smoother and more lustrous than the thorax.

Pubescence of head and thorax very fine, short, appressed, and whitish but hardly conspicuous, mostly confined on head to the cheeks and lower part of the face, sparse on the mesoscutum and scutellum, the latter without larger, more erect setae at apex; eyes bare; abdomen with rather sparse, short, fine pubescence on the sides and somewhat longer setae at the apex and on the ovipositor sheaths.

Coloration nonmetallic, rather dull black or brownish black, with cream-colored or pale buff markings on the head and part of the thorax.

Male.-Very similar to the female, but the head is a little shorter and wider, the eyes smaller, the cheeks proportionately longer, the frontovertex wider or no longer than broad, the ocelli arranged in 
a right-angled triangle. Scape shorter, just reaching to the plane of the frons; pedicel not much longer than thick, shorter than the first funicle joint; flagellum cylindrical, moderately long, clothed with numerous, uniformly scattered, semierect short setae; first funicle joint slenderer than pedicel and about twice as long as thick, the following joints decreasing a little in length, the sixth about one-half longer than thick; club solid, slenderly oval, somewhat pointed at apex, a little longer than the last two funicle joints combined. Abdomen similar in shape, the cercal plates situated somewhat beyond the middle.

TACHARDIOBIUS NIGRICANS, new species

Plate 1, figs. 3 and 4 ; plate 2, figs. 24 and $24 a$

Female.-Head slightly brownish black, with pale cream-colored marks as follows: A small spot anteriorly on the ventroposterior orbits of eyes, two pairs of small spots on dorsal orbits at the anterior and posterior corners of the frontovertex, three spots in a transverse line on the face at the middle of the scrobes, the outer spots between scrobes and eyes, the middle one on the triangular prominence between the scrobes; but sometimes the whole ventroposterior orbits are narrowly pale and three sometimes partly confluent marks may occur on the oral margin, the middle one of these in the form of an elongate triangle placed vertically between the antennal sockets, the outer spots situated beneath the sockets. Thorax black, the pleura sometimes more or less brownish; collar of the pronotum sometimes with a small creamy white dot on the posterior corners, the prepectal plates transparent whitish and anterior margin of the mesopleura sometimes creamy white or pale buff; posterior margin of collar except at the sides also sometimes narrowly whitish; tegulae creamy white at the base. Abdomen black, the protruding tip of ovipositor sheaths brownish yellow. Scape and pedicel fuscous, the apical margin of the pedicel whitish; flagellum brownish to rather dark fuscous. Legs varying from brownish to fuscous on the darker parts; in the darker specimens the coxae, trochanters, and femora are nearly black, with the middle trochanters, apex of middle femora, and knee joint of front and hind legs creamy white or yellowish; front tibiae fuscous with an obscure paler spot on outer surface before the apex, the front tarsi brownish at base and with the two apical joints fuscous; middle and hind tibiae yellowish, with two fuscous rings just before and beyond the middle and with a much narrower, more or less incomplete brownish ring at apex; spur of middle tibiae and first joint of middle tarsi pale creamy yellow or whitish, the tarsi gradually growing darker distad, the apical joint fuscous; hind tarsi brownish, the 
basal joint somewhat yellowish white, the last two joints more or less fuscous. In paler specimens the front femora have incomplete whitish annuli near the base and the apical ring is much wider; the apex of front coxae and the front trochanters yellowish white; middle femora almost wholly whitish on the outer margin, the dark ring at apex of hind tibiae very obscure or obsolete, the middle and hind tarsi not much infuscated except on the apical joint. Wings hyaline, the veins brownish.

Length of body, (1.04 to) 1.73 ; length of head, 0.128 ; width of head, 0.537; width of frontovertex, 0.221 ; length of antenna, 0.806: width of mesoscutum, 0.526 ; length of fore wing, 1.437 ; widt ${ }_{3}$ of fore wing, $0.657 \mathrm{~mm}$.

Male.-Very similar to the female, except that the pale markings on the head are larger and more or less confluent, the orbital mark on cheeks sometimes uniting with the dot between the scrobes and the eyes and then with the dot on the anterior corners of the frons, also broadening to join the spots below the antennal sockets, so that the whole lower part of the face is pale except for an invertei! $V$-shaped mark between the antennal sockets and oral nargin; flagellum brown.

Length of body, (1.17 to) 1.29 ; length of head, 0.344 ; width of head, 0.438 ; width of frontovertex, 0.200 ; length of antenna, 0.763 ; width of mesoscutum, 0.412 ; length of fore wing, 0.992 ; width of fore wing, $0.462 \mathrm{~mm}$.

Described from 16 females and 10 males (holotype female, allotype, and paratypes) reared February 3 to April 5, 1919, from Tachardiella larreae (Comstock) on greasewood, collected at Arlington, Arizona, January 23, 1919 (Charles H. Gable). The parasites were reared out at Washington, D. C., by C. S. Menagh.

Type.-Cat. No. 28144, U.S.N.M.

Two females reared from the same host collected at Pigeon Pass, near Riverside, California, January, 1908, (Califomia State Insectary), are apparently the same species but are not included among the types. They differ in having the pale markings on the head very faint and partly obsolete.

\section{GAHANIELLA, new genus}

Similar in some respects to Agromyzaphagus Gahan and comes next to that genus in my manuscript table of genera. In Mercet's table of genera the female runs to Ooencyrtus and the male to the first alternative in couplet 87 , where it runs out, as the occipital margin is acute and the thorax is not at all brilliant netallic. This genus is named for A. B. Gahan, of the United States National Museum, in recognition of his careful work on parasitic Hymenoptera.

Genotype.-Gahaniella californica, new species. 
Femate--Head moderately thin frontooccipitally, somewhat wider than long, the face inflexed; as seen in dorsal view well rounded on the sides, transverse in front between the eyes, and slightly emarginate in a broad curve at occipital margin; in side view about onehalf as thick as long, the planes of the face and frontovertex meeting in an obtuse angle; as seen from in front widest a little above the lower ends of the eyes, well rounded on the sides above this point, gently rounded medially above and with the cheeks converging toward the mouth, so that if the lines were continued they would meet in an acute angle, but they are truncated by the oral margin, which is transversely arched. Occiput weakly concave, the dorsal margin acute; eyes rather small, nearly circular in outline and bordering the occiput posteriorly; frontovertex slightly broader than long, more nearly one-half than one-third as wide as the whole head; ocelli large, arranged in a large right-angled triangle, the posterior pair about their own diameter from the eye margin and much closer to the occipital margin; cheeks as long as the eyes, without a genal suture, and arcuately converging. Face wider than long, rather depressed; the antennae inserted close together far above the oral margin and about on the ocular line, the space between the sockets one-half or less than one-half the distance between the sockets and oral margin; the upper half of face between the eyes with two deep linear sulcate scrobes, which are close together, nearly parallel and reaching to the angulation separating the face from the frons; prominence between the antennae very narrow and carinalike above where it separates the scrobes, but below the antennae it broadens out triangularly and extends nearly to the oral margin; sometimes through shrinkage of the head the face has a large, rather deep, quadrangular depression, with the two basal sides longer than the ventral sides.

Antennae with the scape short, projecting but slightly beyond plane of the frons, and including the radicle shorter than the following four joints combined, in shape subclavately cylindrical; pedicel hardly longer than thick; funicle six-jointed, the joints subequal in length, scarcely increasing in width distad, the first as long as wide and about as wide as the pedicel, the sixth slightly wider than long; club small, oval, three-jointed, a little shorter than the three preceding joints combined; all the joints of the flagellum with linear, longitudinal sensoria.

Mandibles broadly truncate at apex, with a slight emargination at the outer corner, the apex lying in the same plane as the base. Maxillary palpi four-jointed, rather short, the first three joints decreasing in length, the second thickest, the third smallest and thinnest, the fourth slightly fusiform, slender and very pointed at apex, nearly as long as the preceding joints combined; labial palpi short and 
stout, three-jointed, the first and last joints subequal, the middle one triangular, being extremely short on the inner side, and about one-half as long on the outer side as the apical joint.

Thorax strongly convex above, about one-third longer than wide; pronotum strongly arcuate; mesoscutum about twice as wide as long; axillae very short and acute, nearly or quite meeting medially; scutellum nearly as long as the scutum, very convex or pulvinate, the sides high and abruptly declivous, the apex rounded; propodeum very short medially, lengthening toward the sides and strongly declivous behind. Abdomen a little shorter than the thorax, strongly depressed, triangular; the cercal plates situated near or slightly basad of the middle; ovipositor sheaths not or barely protruded.

Legs about normal in length and structure; middle tarsi stouter than the hind pair, somewhat tapering, the first joint nearly as long as the following joints combined; the spur of the middle tibiae nearly as long as the first tarsal joint. Wings short and broad, strongly triangular; discal pubescence extremely short, fine, and rather dense, the basal area with coarser, sparser setae, the marginal fringe also short and dense; speculum indistinct above and broadly separated below from the posterior margin; submarginal vein reaching the costal margin before the middle of the wing, nearly uniformly arcuate from base to apex, slender throughout; marginal vein about twice as long as wide, and fully twice as wide as the submarginal; postmarginal wide at base, abruptly tapering, and about one-half as long as the marginal; stigmal very short, or no longer than the marginal, triangularly widened at apex, the base constricted. Hind wings wide, the costal cell practically absent.

Head and thorax microscopically reticulate, the reticulations of the frontovertex more or less thimblelike and interspersed with fine, shallow pin punctures; scutellum very finely striolate over a greater part of the surface or in part with minute thimblelike punctures; abdomen smoother and more shiny than the thorax, but nevertheless reticulate except on the first tergite. Eyes bare; head and thorax with numerous fine, short setae, which are seriately arranged on the mesoscutum and not conspicuously colored. General color submetallic black.

Male.-Very similar to the female, except in regard to the antennae; head considerably thinner frontooccipitally, the vertex broader, the ocelli larger; scape very short or no longer than the following three joints combined, clavate; pedicel no longer than thick, much shorter than the following joint; funicle joints over twice as long as wide, the first one slightly the longest, the others subequal, each flat beneath, convex above, except the sixth, which is much less so, and each with a scattered whorl of long curved setae; club narrowly oval, about as long as the last two funicle joints combined, two. 
jointed in californica but entire in saissetiae, and with a few scattered setae which are shorter than the hairs on the funicle and decrease in length toward the apex.

GAHANIELLA CALIFORNICA, new species

Plate 1 , fig. 6 ; plate 2 , figs. 15 and 18

Female.-Antennal sockets about equidistant from the eyes and the oral margin; scape proper about three times as long as wide, pedicel nearly globular, club perfectly oval and rounded at base. Frontovertex somewhat more roughly scultpured than the rest of the head, with the reticulations somewhat thimblelike, the fine pin punctures rather numerous; scutellum finely striolate but becoming reticulate at apex, both mesoscutum and scutellum with numerous very minute setiferous punctures seriately arranged; propleura and prepectal plates comparatively coarsely and longitudinally reticulate, mesopleura finely reticulate, the propodeum smooth. Pubescence on head very fine, short, semiappressed, and although rather abundant on the lower part of the face and on the frontovertex, it is hardly visible except under high magnification; pubescence on mesoscutum and scutellum longer, but on account of its dark color it is not conspicuous; the apex of the scutellum mostly bare except for a pair of longer, more erect setae; pubescence of abdomen very fine and dark-colored above, being most abundant along the margins and at apex; the venter also rather densely pubescent with fine appressed hairs.

Coloration shining black, the frontovertex, thorax above, and the abdomen with a slight greenish luster, the scutellum a little duller; face, cheeks, and under parts of thorax somewhat bluish, mandibles brown; antennae brownish, the scape except the radicle and the pedicel except apical margin fuscous. Legs brownish to fuscous, the middle and hind femora inclining to brown; trochanters and front tibiae and tarsi yellowish brown; apex of middle femora, the middle tibiae at base and apex, apex of hind tibiae narrowly and the middle and hind tarsi pale yellow, the middle tibiae broadly and rather indefinitely brownish otherwise; the last joint of middle tarsi and last two joints of hind tarsi brown. Wings hyaline, the veins brownish with the marginal vein darker and more conspicuous than the rest of the venation.

Length of body, (1.26 to) 1.34; length of head, 0.459 ; width of head, 0.55 ; width of frontovertex, 0.254 ; length of antenna, 0.777 ; width of mesoscutum, 0.506 ; length of fore wing, 1.067 ; width of fore wing, $0.525 \mathrm{~mm}$.

Male.-Very similar to the female in structure and coloration, but the head much thinner frontooccipitally, the frontovertex nearly twice as wide as long, the ocelli in an obtuse-angled triangle, the 
antennae differing as noted in the generic description, the club twojointed, the scape and pedicel dark brown, the flagellum pale brown.

Length of body, (1.12 to) 1.32; length of head, 0.457 ; width of head, 0.549 ; width of frontovertex, 0.271 ; length of antenna, 0.940 ; width of mesoscutum, 0.527 ; length of fore wing, 1.121 ; width of fore wing, $0.563 \mathrm{~mm}$.

Described from two females and two males (holotype female, allotype, and paratypes) reared from a species of Lecanium (probably L. corni) on Quercus californica and from Lecanium corni Bouché on Arctostaphylos, July 29 to August 4, 1912, collected at Idyllwild, Strawberry Valley, San Jacinto Mountains, California, on July 12 and 13 (Timberlake), U. S. Insectary No. $14654 \mathrm{~F}$ and G.

Type.-Cat. No. 28145, U.S.N.M.

GAHANIELLA SAISSETIAE, new species

Plate 1, fig. 12 ; plate 2, fig. 17

Female.-Very similar to californica, but the following differences are apparent: Frontovertex a little wider in proportion to the length; the ocelli in an obtuse angle of about $95^{\circ}$ or a little more; the face with an oval depression, apparently not due to shrinkage, divided medially by the antennal prominence, the scrobes not so distinctly sulcate, the prominence above the sockets tapering off to an ill-defined carina which separates the upper half of the scrobes; space between each antennal socket and nearest point of corresponding eye distinctly less than distance from the socket to the oral margin, the antennae being inserted slightly higher up on the face. Antennae a little longer, the scape narrower, more fusiform, excluding radicle a little over four times as long as wide; pedicel slightly longer than wide, and a little shorter than the following joint, the first three funicle joints a trifle longer than wide, the last three about as wide as long, club less perfectly oval and more truncate at base. Sculpture similar, but the reticulations of the frontovertex are more thimblelike and decidedly coarser, the fine pin punctures much sparser and fainter; the scutellum is microscopically shagreened with extremely minute thimblelike punctures which are longitudinally lengthened toward the base and gradually change to longitudinal striolations. Pubescence on head more conspicuous, as it is somewhat whitish and glistening, but considerably sparser on the frontovertex, where it is mostly confined to the orbits.

Coloration similar to californica, but with considerably more metallic luster in parts, the frontovertex much more distinctly greenish, the face and cheeks strongly bluish and rather brilliant, the facial impression greenish in some aspects; scutellum especially toward apex more or less bronzy; the declivous sides of scutellum, metapleura, and basal tergites of abdomen more or less shiny and 
metallic greenish; base and apex of scape and apex of pedicel yellowish, the antennae otherwise as in californica; coxae and femora blackish, the hind femora with metallic luster, all trochanters yellowish, the front tibiae and tarsi pale brown, apex of front and middle femora, the middle tibiae excepting a broad fuscous ring at the middle, base very narrowly and apex of hind tibiae, and the middle and hind tarsi pale yellow, with only the tip of pulvillus of the apical joint of the tarsi dark; wings hyaline, the veins brownish.

Length of body (0.92 to) 1.30 ; length of head, 0.459 ; width of head, 0.532; width of frontovertex, 0.247 ; length of antenna, 0.803 ; width of mesoscutum, 0.523 ; length of fore wing, 1.079 ; width of fore wing, 0.518 ; length of ovipositor sheaths, $0.047 \mathrm{~mm}$.

Male.-Similar to the male of californica, but differing in coloration and sculpture in the same way that the female does; antennae similar, the scape a little slenderer and more fusiform or widest near the middle, the first funicle joint longest, over twice as long as wide, third to fifth joints about twice as long as wide, the second and sixth joints a little shorter, the sixth a little more than half longer again than wide, club one-jointed, oval, pointed at apex, about as long as the last two and one-half preceding joints combined, the arrangement of hairs on the flagellum about the same.

Length of body, 0.91 ; length of head, 0.342 ; width of head, 0.390 ; width of frontovertex, 0.189 ; length of antenna, 0.685 ; width of mesoscutum, 0.368 ; length of fore wing, 0.833 ; width of fore wing, $0.404 \mathrm{~mm}$.

Described from two females and one male (holotype female, allotype, and paratype) reared April 13-14, 1922, from Saissetia nigra (Nietner) at the experiment station, St. Croix, Virgin Islands, West Indies (C. E. Wilson).

Type.-Cat. No. 28146, U.S.N.M.

MAYRIDIA AMERICANA, new species

Plate 1, figs. 9 and 13 ; plate 2, figs. 21 and $21 a$

Closely allied to $M$. bifasciatella (Mayr), but differs in having the hyaline crossband of wings composed of two opposed triangular spots, the frontovertex of female twice as long as wide, the antennae of the male very much longer, etc.

Female.-Head thick frontooccipitally, the face inflexed; as seen from above the occipital margin is broadly and slightly arcuately emarginate, the sides obliquely rounded and somewhat converging toward the front, the head being widest close to the occipital plane, the frontal margin nearly transverse medially; as seen from in front a little wider than long, full rounded above, the dorsal surface of 
head being strongly convex from side to side, but the cheeks subarcuately converge toward the broadly truncate oral margin; as seen from the side the outline of head is subtriangular, the occipital margin bulging moderately, the facial side nearly straight, about one-fourth longer than the dorsal side and meeting its plane in an angle of about $90^{\circ}$, the dorsal outline moderately rounded, sloping forward and downward, its angulation with the face rounded off. Occiput a little concave, the neck inserted near the center, its dorsal margin rounded; eyes moderately large, broadly subtriangularly oval, strongly diverging below in frontal vein of head, the posterior margin slightly emarginate, the facial margin about one-half as long as the dorsal margin and forming an obtuse rounded angulation with it; frontovertex less than one-third as wide as the whole head, nearly twice as long as its posterior width and slightly widening anteriorly; ocelli in an equilateral triangle, the anterior ocellus near the center of the frontovertex, the posterior pair about one-half their own diameter from the eye margin and remote from the occipital border; cheeks not short, yet considerably shorter than the width of the eyes, the genal suture very distinct; face very slightly convex from side to side, the antennal sockets situated nearly on the ocular line, more than twice their own length apart, distinctly closer to the eye margin than to each other and about equidistant from each other and the oral margin; scrobal impression above the sockets rather shallow, short, and semicircular, its margin not sharply angulated but vague, its cavity divided medially for about two-thirds of its length by the obscurely triangular prominence between the sockets.

Antenna hardly more than one-half as long as the body, moderately clavate; scape slender, a little compressed, slightly the widest near the middle, reaching for nearly one-half of its length beyond the scrobal impression; pedicel somewhat more than twice as long as thick at apex, distinctly longer than the following joint but not equal to the next two joints combined; funicle joints about equal in length but increasing considerably in width distad, the first longer than wide, slenderer than the pedicel, the second similar, but wider, the sixth nearly twice as wide as long; club pointed ovate, rounded at apex, as broad at base as the preceding joint and as long as the last three funicle joints combined, its three joints subequal in length.

Mandibles with three acute, nearly equal teeth, the apex a little oblique to the basal expansion but not so much that it can not be seen when the mandible lies flat. Maxillary palpi four-jointed, the third joint a little longer than thick, the second somewhat longer than the third, the basal joint about twice as long as the third, the apical joint nearly twice as long as the basal and slenderly fusiform; labial palpi three-jointed, stout, the basal joint the thickest and 
longest, the other two about one-half as long, the apical one thinnest.

Thorax about twice as long as wide, only slightly convex above, the width distinctly greater than the depth; pronotum conical and visible in large part, its posterior margin arcuate; mesoscutum less than twice as wide as long; axillae moderately long at their outer ends, acutely meeting medially; scutellum somewhat shorter than the scutum, longer than wide in the apterous form and acute at. apex, about as long as wide and more rounded at apex in the macropterous phase, the disk depressed, the sides abruptly declivous but not very strongly elevated; propodeum obliquely declivous toward apex, rather short medially.

Abdomen ovate, depressed, rather acute at apex, about as long as the thorax; the tergites not greatly unequal in length, the seventh longest medially, the third, fourth, and sixth shortest; cercal plates situated at the middle of the lateral margins; venter not compressed, ovipositor not inclosed apically by the ventrites, the sheaths just barely protruded.

Legs of normal length and structure, the middle tarsi stouter than the hind pair, tapering towards apex, the spur slightly shorter than the first joint. Wings generally rudimentary and reaching about to the apex of the propodeum, truncate at apex; when fully developed they are moderately wide and surpass the apex of abdomen, marginal fringe short; discal setae rather dense and fine, quite as dense on the hyaline median crossband but white and almost invisible when wing is mounted in balsam, much sparser and also hyaline in the clear area beneath the basal half of the venation; costal cell narrow, and with two or three rows of very fine, hyaline setae on the basal half; speculum distinct, strongly oblique, and widening below; submarginal vein nearly straight, marginal about four times as long as wide, the stigmal subequal to the marginal, only slightly widened toward the apex, the postmarginal about one-half as long as the stigmal; spur of the stigmal vein reaching about opposite to the middle of the costal margin.

Frontovertex finely punctulate, the punctures thimblelike, not quite uniform in size, being distinctly finer around the ocelli and interspersed with a few shallow pin punctures; face rather more finely reticulate; cheeks equally finely longitudinally reticulate-striolate; mesoscutum minutely scaly reticulate; scutellum densely longitudinally shagreened with alternate fine striae and broken lines, the axillae with a similar obliquely transverse sculpture; pleura smoothish, the propleura and prepectal plates finely reticulate, the mesopleura more finely and longitudinally reticulate; propodeum smooth; abdomen uniformly reticulate, except that the first tergite is smooth across the base, with the meshwork distinctly coarser than that of the mesoscutum or face. 
Head with sparse, fine, inconspicuous pubescence on the cheeks and frontovertex, the face mostly bare, the eyes with a few erect extremely short setae; mesoscutum sparsely set with fine, palecolored, seriately arranged setae, the scutellum with a few similar setae on the disk medially, and a pair of longer setae at apex; lateral margins of propodeum with a small patch of white pubescence; abdomen with sparse setae, mostly along the sides and at apex, but the basal tergite with a transverse row on each side not far from the apical margin.

General color rather dark aeneous green, the face and cheeks brighter green, with a brilliant golden luster or with a reddish luster at the oral margin and over a greater part of the cheeks; mesoscutum, apical margin of scutellum in certain aspects, and lateral margins of propodeum light metallic green, the axillae and remainder of scutellum much darker and duller; pleura and sternum of thorax, tegulae, propodeum, and lateral margins of mesoscutum, more or less widely and distinctly, yellowish brown to rather dark brown or even brownish fuscous, the propleura with a metallic luster; abdomen sometimes somewhat bluish black, but usually light green with a bright luster at the base. Antenna brownish yellow, the scape and club palest, the pedicel and funicle more or less embrowned. Legs brownish yellow, the apex of middle tibiae, spur, and middle tarsi palest, the hind femora and tibiae much darker or more or less brownish fuscous; a very narrow ring at base of hind tibiae and apex of the same more or less broadly pale; apical joint of all the tarsi fuscous. Brachypterous wing hyaline or whitish, sometimes a little infuscated at apex; macropterous wing rather deeply infuscated, but with the basal fourth and a band across the widest part just beyond the apex of the venation hyaline, the band composed of two subtriangular areas opposed at their apices; subbasal infuscated band extending from just beyond the middle of the submarginal vein to slightly beyond the apex of the stigmal vein, both its basal and its apical margin straight and transverse, but the band is somewhat interrupted by a curved subhyaline streak subparallel to the posterior margin and placed about one-fifth of the width of the wing from the margin; veins pale brownish yellow, with the apical half of the submarginal, the marginal, and postmarginal veins darker; hind wings hyaline.

Length of body, (1.48 to) 1.87 ; length of head, 0.495 ; width of head, 0.572 ; thickness of head, 0.292 ; width of vertex, 0.200 ; length of antenna, 0.874 ; width of mesoscutum, 0.481 ; length of macropterous fore wing, 1.496; width of macropterous fore wing, $0.606 \mathrm{~mm}$.

Male.-Form much slenderer and less robust than in the female; head rather thin frontooccipitally; as seen from above transversely 
subquadrate, the sides rounded, the margin in front broadly transverse, the occipital margin broadly slightly concave; as seen from in front broader than long, the curvature depressed above, strong on the sides dorsad, the cheeks arcuately converging toward the mouth; as seen from the side the facial outline is about straight and twice as long as the dorsal side, which is convex, the planes meeting in an obtuse angle, the occipital margin slightly bulging. Occiput moderately concave; eyes much smaller than in the female but similar in shape; frontovertex a little broader than long, its occipital margin rounded off; ocelli in a large, distinctly obtuse angle, the posterior pair remote from the occipital border and their own diameter from the eye margins, the anterior ocellus placed a little in front of the center of the frontovertex; cheeks wide and about as long as the width of the eyes, the genal suture distinct. Face moderately convex from side to side, with a very slightly elevated narrow ridge medially from the level of the antennal sockets nearly to the oral margin, a depression below antennae also present in some specimens, due to shrinkage; antennal sockets situated moderately far apart at the middle of the head, distinctly above the ocular line and hardly more than their own length from the rounded angulation between the face and frons, about their own length apart and slightly less than their own width from the eye margins; scrobes extremely short, extending obliquely inward and uniting, each about one-half as long as the sockets and together forming a shallow lunate depression slightly emarginated medially above.

Antenna slender, about three-fourths as long as the body, scape very short and stoutly fusiform yet reaching well beyond the scrobal impression; pedicel only slightly longer than thick, very much shorter than the following joint; flagellum long, slender, increasing very slightly in thickness distad, clothed with numerous uniformly distributed longish semierect setae, the first three funicle joints with a much longer curved seta at apex on the dorsal side; funicle joints all longer than thick, the basal joint cylindrical and by far the longest, about six times as long as thick and as long as the scape, the sixth slightly less than one-half as long as the first and somewhat less than twice as long as wide; club oval, entire, pointed at apex, and a little longer than the two preceding joints combined.

Thorax similar to the female but narrower, the mesoscutum relatively longer, scutellum longer than wide, rather acute at apex; abdomen depressed, ovate, about two-thirds as long as the thorax; wings fully developed and similar to the fully developed wings of the female.

Sculpture coarser but similar; frontovertex much more reticulate than in the female, or about like the face and with scattered shallow 
pin punctures; mesoscutum almost as coarsely reticulate as the abdomen, the scutellum sculptured as in the female. Pubescence on the face and cheeks more abundant and conspicuous than in the female, yet rather sparse.

Coloration similar to the female, but the head is brighter green with a more brilliant luster, the face bright blue-green, the frontovertex with a variable reddish and golden luster; tegulae, propodeum and under parts of thorax shiny fuscous or black; scape about yellow ocher (Ridgway), the pedicel and flagellum pale brown; legs nearly uniformly yellow, about yellow ocher of Ridgway, the middle coxae fuscous except at apex, the front tarsi slightly dusky, the last joint of middle and hind tarsi fuscous; wings as in the female, but with the banding much fainter although distinct.

Length of body, (1.22 to) 1.53 ; length of head, 0.438 ; width of head, 0.492 ; thickness of head, 0.283 ; length of antenna, 1.13 ; width of mesoscutum, 0.433 ; length of fore wing, 1.33 ; width of fore wing, $0.558 \mathrm{~mm}$.

Described from three females and one male (holotype female, allotype, and paratypes) reared from Trionymus utahensis (Cockerell) on Elymus, Salt Lake City, Utah, August 24 to September 20, 1915 (Timberlake); two males (paratype) from the same host and locality, April 13, 1911 (C. N. Ainslie), Webster No. 6650; one male (paratype) presumably from the same host on Elymus condensatus, Kimballs, Utah, August 13, 1912 (C. N. Ainslie), Webster No. 8823; four females (paratypes) from Tower City, North Dakota (G. I. Reeves), Webster No. 2559; and one female (paratype) reared from a mealy bug on Elymus at Tabor, South Dakota, August 8, 1913 (C. N. Ainslie), Webster No. 11801.

The females are all brachypterous except two from Tower City, North Dakota, and one of these has the fore wings very short, although the hind wings are fully developed. The males are all macropterous.

Another female reared by C. N. Ainslie from the same host at Salt Lake City, Utah, in September, 1912, apparently represents another species of Mayridia, as the head is much thinner and more obliquely inclined.

Type.-Cat. No. 28147, U.S.N.M. 


\section{EXPLANATION OF PLATES}

\section{Plate 1}

FIG. 1. Vosleria signata Timberlake. Antenna of female.

2. Pseudorhopus hartmani Timberlake. Antenna of female.

3. Tachardiobius nigricans Timberlake. Antenna of male.

4. Tachardiobius nigricans Timberlake. Antenna of female.

5. Cyrtocoryphes viridiceps Timberlake. Antenna of female.

6. Gahaniella californica Timberlake. Antenna of female.

7. Vosleria signata Timberlake. Head of female in frontal view.

8. Aztecencyrtus Alavus Timberlake. Antenna of female. The shape of the club is hypothetical.

9. Mayridia americana Timberlake. Antenna of male.

10. Hexacnemus armitagei Timberlake. Antenna of female.

11. Pseudorhopus hartmani Timberlake. Antenna of male.

12. Gahaniella saissetiae Timberlake. Antenna of female.

13. Mayridia americana Timberlake. Antenna of female.

\section{Plate 2}

14. Pseudorhopus hartmani Timberlake. Middle leg of female.

15. Gahaniella californica Timberlake. Antenna of male.

16. Hexacnemus armitagei Timberlake. Antenna of male.

17. Gahaniella saissetiae Timberlake. Antenna of male.

18. Gahaniella californica Timberlake. Venation of fore wing of female.

19. Cyrtocoryphes viridiceps Timberlake. Mandible of female in frontal view.

19a. Cyrtocoryphes viridiceps Timberlake. Mandible of female in ventral view.

20. Hexacnemus armitagei Timberlake. Venation of fore wing of female.

21. Mayridia americana Timberlake. Mandible of female in dorsofrontal view.

21a. Mayridia americana Timberlake. Mandible of female in dorsal view.

22. Aztecencyrtus flavus Timberlake. Mandible of female in frontal view.

22a. Aztecencyrtus flavus Timberlake. Mandible of female in ventral view.

23. Hexacnemus armitagei Timberlake. Mandible of female in frontal view.

23a. Hexacnemus armitagei, Timberlake. Mandible of female in dorsal view.

24. Tachardiobius nigricans Timberlake. Mandible of female in frontal view.

24a. Tachardiobius nigricans Timberlake. Mandible of female in dorsal view. 


\section{$2 \mathrm{BHL}$ Biodiversity Heritage Library}

Timberlake, P. H. 1926. "Miscellaneous new chalcid-flies of the hymenopterous family Encyrtidae." Proceedings of the United States National Museum 69(2629), 1-34. https://doi.org/10.5479/si.00963801.69-2629.1.

View This Item Online: https://www.biodiversitylibrary.org/item/52772

DOI: https://doi.org/10.5479/si.00963801.69-2629.1

Permalink: https://www.biodiversitylibrary.org/partpdf/51025

\section{Holding Institution}

Smithsonian Libraries

\section{Sponsored by}

Smithsonian

\section{Copyright \& Reuse}

Copyright Status: Public domain. The BHL considers that this work is no longer under copyright protection.

This document was created from content at the Biodiversity Heritage Library, the world's largest open access digital library for biodiversity literature and archives. Visit BHL at https://www.biodiversitylibrary.org. 